\title{
The Effect of Compatibilizer Addition on Chlorella vulgaris Microalgae Utilization as a Mixture for Bioplastic
}

\author{
Dianursanti $^{1, *}$, S A Khalis ${ }^{2}$ \\ ${ }^{1}$ Chemical Engineering, Faculty of Engineering Universitas Indonesia, Depok 16424, Indonesia. \\ ${ }^{2}$ Bioprocess Engineering, Faculty of Engineering Universitas Indonesia, Depok 16424, Indonesia.
}

\begin{abstract}
Nowadays, plastic waste is the biggest environmental issues. Since the usage of conventional plastic which come from synthesis polymer that can not be decomposed by decomposer. One of the solution is bioplastic. This study used Chlorella vulgaris and PVA as the based materials to made bioplastic. Chlorella vulgaris is chosen as the new potential of raw material for its high amount of biopolymer (Protein, carbs). However, Chlorella/PVA has some weakness such as poor physical- chemical properties. Compatibilizer is needed to improve the homogeneity and compatibility of natural and synthetic mixtures as both materials have different properties. This study aims to obtain the best maleic anhydrates concentration as compatibilizer for PVA-Chlorella plastic based. Maleic anhydrate-grafted PVA (PVA-g-MAH) was synthesized by blending PVA, maleic anhydrate, DMSO and KPS with temperature $120^{\circ} \mathrm{C}$. Chlorella was modified by mixing distillated water and glycerol. Both of them are mixed well then molding by temperature $120^{\circ} \mathrm{C}$. The addition of maleic anhydrates concentration $(2 \%$, $4 \%, 5 \%$ wt of PVA) respectively improve surface structure and cause increasing in tensile strength from 31.27 to $42.25 \mathrm{kgf} / \mathrm{cm}^{2}$ and also increasing elongation from 10.86 to $13.00 \%$. With this result, it can be indicated that compatibilizer addition can improve the homogeneity and elasticity the mixture of PVAChlorella plastic film.
\end{abstract}

Keywords: Chlorella vulgaris; PVA; Compatibilizer; Maleic anhydrates; Bioplastic

\section{Introduction}

Petroleum based plastic is a material that is often used in everyday life. Most of them are usually disposable like packaging and they will become plastic wastes. Plastic consumption is expected to keep increasing along with the increase of public plastic demand that will lead to accumulation in plastic landfills (Wisojodharmo, 2001)[1]. Conventional plastics constituents comprising of toxic chemicals have negative impacts such as water, land, and air pollution around landfill.

The alternative that can be done is to modify or replace plastic raw material (fossil based) with other environmentally friendly such us biodegradable plastic made of renewable material of fossil based but with the combination biodegradable additives. Natural additives can be used as mixture or raw material are polysaccharides comprising starch, lignin-cellulose, pectin, and chitosan and protein and lipid derived from animals that produce casein, collagen, and gelatin. The use of those materials as plastic constituents however compete with food application.
Microalgae is a potential additive as biodegradable plastic constituent. The benefit of using microalgae for producing plastic is greater than terrestrial crops, such as higher yield, faster growth, sea water and fresh water can be used as medium, does not compete with food application, few water consumption, and production costs are relatively low (Guerrero, 2007)[2]. The microalgae that have big potential as plastic constituent is from green algae (Chlorophyte) because of its high protein content and renewable biopolymers.

Chlorella vulgaris is a green microalga with high protein content, around $51 \%-58 \%$ dry base. Chlorella vulgaris also has crack resistance because of its round shape and hard cell wall consist of cellulose and pectin (Isnanstevo et al., 1995)[3]. The thermal stability of Chlorella vulgaris also higher than other microalgae such as Spirulina plantesis (Zeller et al., 2013)[4]. In addition, microalgae has fairly small cell size, thus there is no need to isolate the protein from microalgae. These properties allow them to be relatively suitable for plastic fabrication without any prior treatment, making scalable production more cost effective.

PVA or polyvinyl alcohol is selected as a mixed polymeric material in the preparation of this bioplastic.

\footnotetext{
* Corresponding author: dianursanti@yahoo.com
} 
Commercially, polyvinyl alcohol is the most important plastic in the manufacture of water-soluble films. It is characterized by its ability in film formation, emulsifier, and its adhesive properties. The function of adding PVA as a mixture of bioplastic preparations is to increase strength, flexibility, and durability and as a mixture with Chlorella vulgaris biopolymer.

Despite the numerous advantages of PVA, it does not possess thermoplastic properties and cannot be used directly as packaging material. In addition, its end products have poor surface, dimensional stability and mechanical properties. It is shown in the research done by Zhu et al. (2017)[5] is about compatibilizer addition. Polybutylene succinate (PBS) is modified with maleic anhydride into PBS-g-MA as compatibilizer in PBS and Spirulina plantesis mixing. The results show that compatibilizer addition can improve morphology surface from cracking, decrease pores and also increase mechanical properties.

The use of compatibilizer in the mixture with Chlorella and PVA plays an important role in improving mechanical characteristic of the mixture such as tensile strength and elongation. It can help to make interfacial bonding between polymer and biopolymer to homogenity the mixture. Maleic anhydrides has been used to grafted another polymer such as LDPE, HDPE and PBS to blend with stratch and Spirullina plantesis. So far, maleic anhydride has not been used as a compatibilizer for frabication PVA/Chlorella biocomposites. This study was aims to develop PVA/Chlorella biocomposites. So,it can be the viable and suistanable source for replacing or complementing the petroleum based plastic. The effects of compatibilizer on PVA /Chlorella plastic were evaluated by tensile strength, elongation and morphological properties.

\section{Methods}

\subsection{Materials}

Microalgal biomass species Chlorella vulgaris were used to determine their potential for bioplastic production. Chlorella vulgaris powder was purchased from Shaanxi Jintai Biological Engineering Co., Ltd., (China). According to company's compositional information chlorella consist of $58.5 \%$ protein (on dry weight basis). Polyvinyl alchol was purchased from PT. Brataco, with molecular weight $37000 \mathrm{~g} / \mathrm{mol}$. Maleic anhydrides (MA), Pottasium peroxodisulfate (KPS) and Glycerol with a purity $99.5 \%$ were purchased from Sigma-Aldrich

\subsection{Syntesis of PVA-g-MA}

The synthesis of PVA-g-MA was perfomed as describe previously. Briefly, PVA (2.5 g) and Maleic anhydrates with $(2 \%, 4 \%, 6 \%$ of PVA) in $15 \mathrm{ml}$ DMSO were melt blending at $80{ }^{\circ} \mathrm{C}$ for $30 \mathrm{~min}$. Afterward, KSP (1\% of PVA) added into the mixture and tempereature increased to $120{ }^{\circ} \mathrm{C}$. After DMSO was evaporated and the mixture completely homogeneous, then the mixture of PVA-gMA was cooled at room temparature.

\subsection{Preparation of Thermoplastic Chlorella}

$15 \%$ Glycerol from $5 \mathrm{gr}$ algae wt added into $15 \mathrm{~mL}$ of distilled water and stirrer at $60{ }^{\circ} \mathrm{C}$ for $10 \mathrm{~min}$. Then $5 \mathrm{gr}$ Chlorella vulgaris was added and mixed under stirring for $30 \mathrm{~min}$, at the temperature $100{ }^{\circ} \mathrm{C}$.

\subsection{Preparation of Bioplastic Samples}

PVA-g-MA and thermoplastic chlorella (TPC)were mixed afterward, under stirring for $30 \mathrm{~min}$, at the temperature $120^{\circ} \mathrm{C}$. Then the mixture was stored for 24 hour. The mold was made of glass, sized $10 \times 20 \mathrm{~cm}$. The mixture was stirred and heated at $120{ }^{\circ} \mathrm{C}$ for $10 \mathrm{~min}$ befoure poured onto mold. After that, the sample were placed into oven for $15 \mathrm{~min}$ at $100{ }^{\circ} \mathrm{C}$. After the samples were cooled for $10 \mathrm{~min}$ the samples were removed from glass.

\subsection{Mechanical Properties}

Mechanical properties of the bioplastic film that analysed were tensile strength and elongation according to ASTM D822. Tensile strength was the maximum load where the specimen can hold its shape before failure. Elongation was the ratio between maximum length of specimen before failure and its initial length. These characteristics usually showed in stress-strain diagram.

\subsection{Electron Microscopy}

Scanning electron microscopy (SEM) was used to investigate the PVA-g-MA/Chlorella bioplastic. Liquid nitrogen frozen fractured surfaces and tensile fractured surfaces of the composites were dried and sputter-coated with gold prior to examination. The sample chosen is the one with best mechanical properties with magnification 500x and 6000x.

\section{Result and Discussion}

\subsection{General Apperence of Film}

Figure 1 shows the photographic images of film from PVA /Chlorella blending with variations of compatibilizer concentration, whereas, Table 1 describes their visual appearance bye researches evaluation. Film prepared were observe on the surface of the films. This observation could be indicated to the homogenity of PVA/ Chlorella film resultant. 

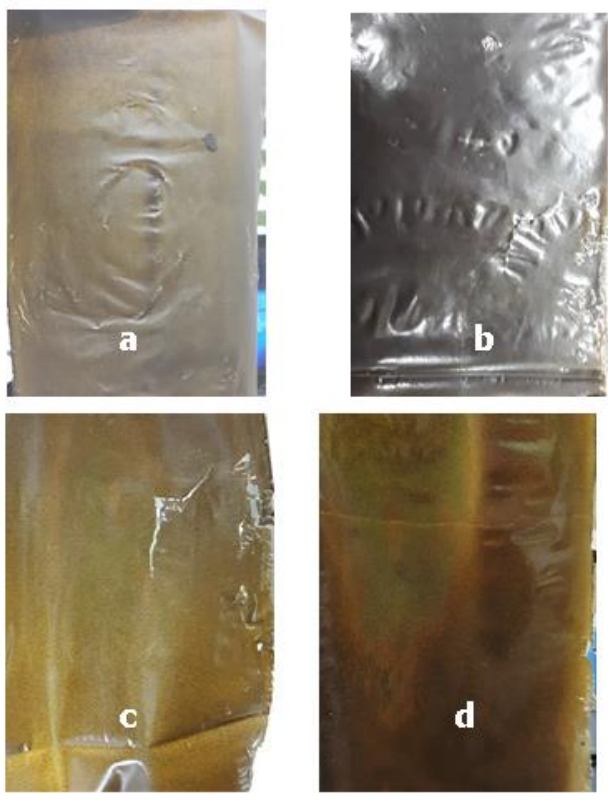

Figure 1. Bioplastic film using different concentration of glycerol (a), PC (b), PCM2 (c), PCM4 and (d) PCM6

Tabel 1. Appearance of film plastic

\begin{tabular}{ccl}
\hline Sample & $\begin{array}{c}\text { Compatibilizer } \\
\text { Concentration } \\
\text { (\%) }\end{array}$ & Appearance Film \\
\hline PC & - & $\begin{array}{l}\text { Rough, brittle, } \\
\text { fragile, many pores, } \\
\text { less flexible, very } \\
\text { difficult to peel }\end{array}$ \\
\hline PCM2 & 2 & $\begin{array}{l}\text { Less pores, more } \\
\text { flexible, less rough } \\
\text { than without, } \\
\text { difficult to peel }\end{array}$ \\
\hline PCM4 & 4 & $\begin{array}{l}\text { Less pores than } \\
\text { M2, slighthy } \\
\text { elastic, easy to peel }\end{array}$ \\
\hline PCM6 & 6 & $\begin{array}{l}\text { No pores, more } \\
\text { flexible, more } \\
\text { elastic, easy to peel }\end{array}$ \\
\hline
\end{tabular}

\subsection{Mechanical Properties of Film}

This test aims to determine the characteristics of mechanical properties of bioplastic films. Testing of bioplastic mechanical properties is the most important test for knowing the homogeneity of a mixture beetwen polymeric and biopolymer materials. The tests performed are on tensile strength and elongation.

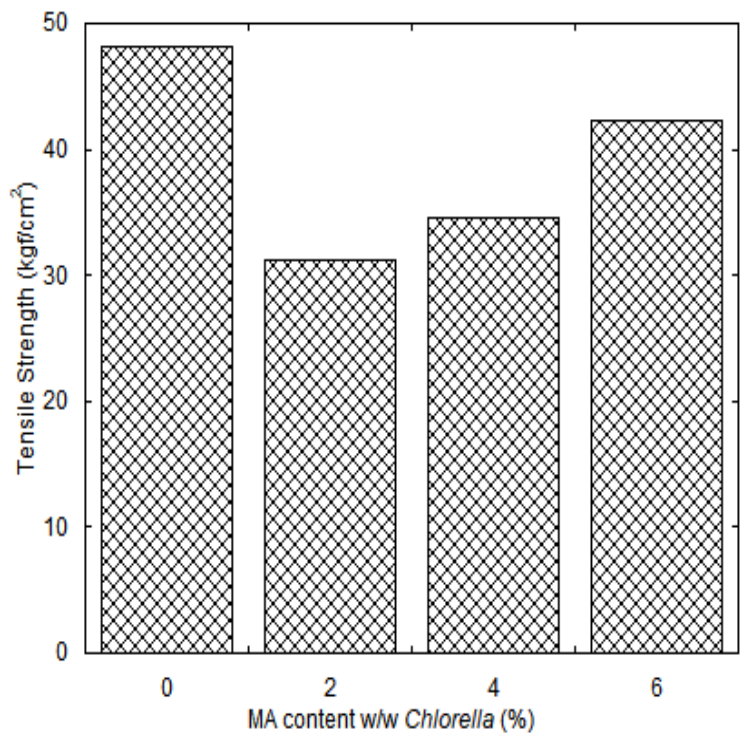

Figure 2. Effect of compatibilizer in mechanical properties for Tensile strength

Figure 2 shows samples without using compatibilizer do show the highest tensile strength value. However, after the addition $2 \%$ of maleic anhydride the value of tensile strength tends to decrease. The occurrence of a drop in tensile strength after maleic anhydride addition as a compatibilizer or the connecting compound is suspected because the thermoplastic Chlorella (TPC) in sample control (without compatibilizer) has not been fully homogenized with PVA or has not formed a bond between the TPC and the PVA polymer. Thus, the resulting plastic tends to be rigid, hard and there are still granules. Meanwhile, after the addition $2 \%$ of compatibilizer it is assumed that the polymerization reaction between TPC (biopolymer) and PVA (polymer) has been occurs, it characterized by a decrease in the value of tensile strength. Then, the value of tensile strength continues to increase as the addition of maleic anhydride $4 \%$ and $6 \%$ respectively. This may indicate that the dispersion of anhydrous groups is more prevalent in the polymer-biopolymer or it can be said that the interaction bond between Chlorella, PVA and MA is increasing. Overall increase in maleic anhydrides concentration tends to increase the tensile strength value of the bioplastic film formed. This is because the anhydra group at MA is highly reactive to the hydroxyl group present in Chlorella vulgaris and causes many bonds formed between thermoplastic Chlorella vulgaris and PVA, resulting in very strong interactions between the two polymer matrices. 


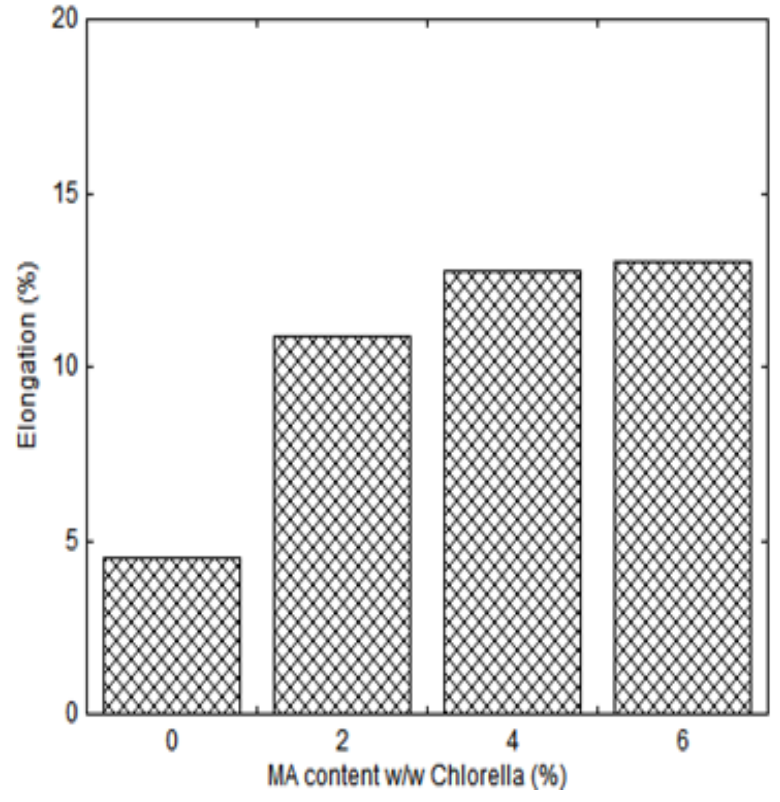

Figure 3. Effect of compatibilizer in mechanical properties for Elongation

Figure 3 shows the increase of compatibilizer concentration from $2 \%$ to $6 \%$ also siginificantly cause increasing film elongations from $10.86 \%$ to $13.0 \%$. The increased value of elongation percentage due to the presence of maleic anhydrides caused polymer blends with different properties (PVA/Chlorella) to become more homogeneous so it would may causes increased the flexibility or elasticity and decrease the stiffness of the formed film mixture. It was also suggested by Chen et al. (2005) in Waryat (2013)[6] suggesting that the presence of a connecting compound or compatibilizer not only increases the mechanical stregth but also the dispersion and adhesion forces between the biopolymer and the polymer.

\subsection{Scanning Electron Microscopy of Film}

Figure 4 and 5 shows the surface film without maleic anhydride as compatibilizer. It can be seen surface area looks so rough, there are so many pores and granules or uneven on the surface area. Also in some part it shows there were some impurities.

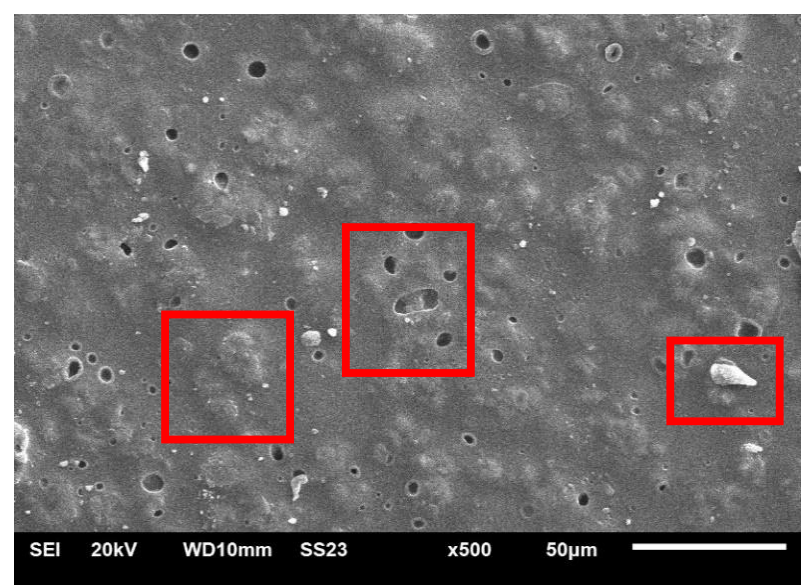

Figure 4. Surface film without compatibilizer

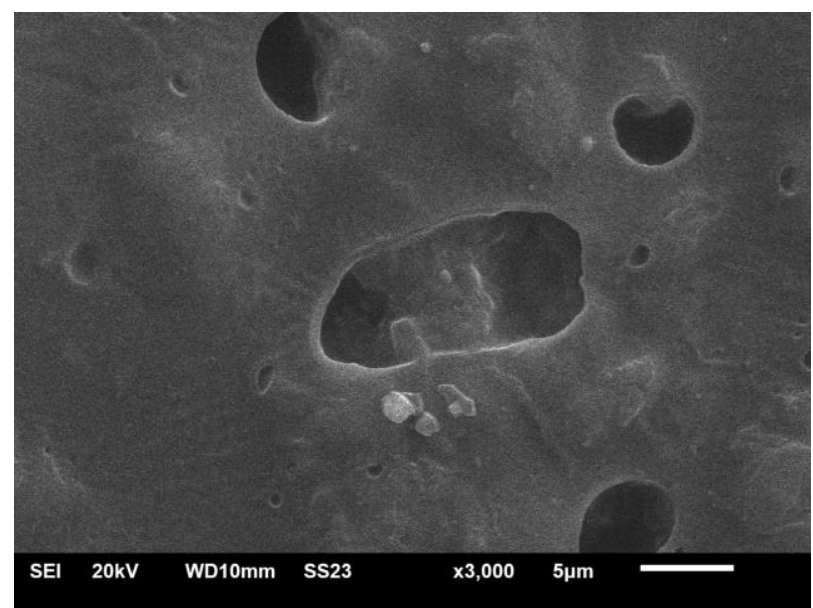

Figure 5. Surface film without compatibilizer (x3000)

Meanwhile figure 6 shows the surface area film with compatibilizer $6 \%$. Addition of maleic anhidrides as compatibilizer to the plastic mixture helps in solubilizing between chlorella and PVA granules completely; enhances the smoothness and cohesiveness of film surface microstructure promotes homogeneous, compact the composites, and dense film surface. Also, as we can see from the figure below there is no cracks or pores in surface area.
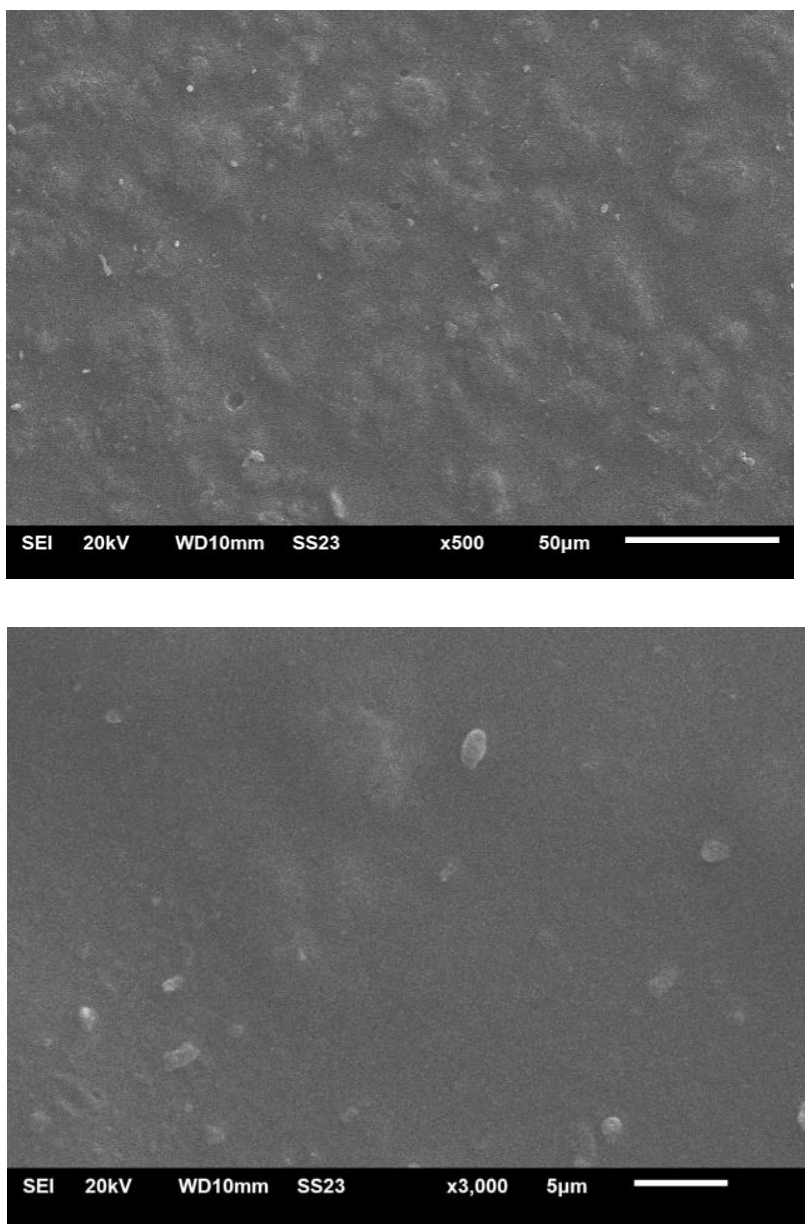

Figure 6. Surface film with compatibilizer $6 \%$ 
The addition of compatibilizer can improve the morphological surface from PVA/Chlorella composites. Meanwhile, the different concentration of compatibilizer in the film forming solution have remarkable effects on the physical, tensile strength and elongation properties of the resulting films. In all the bioplastic films, the tensile strength increased with compatibilizer content from $2 \%$ to $6 \%$ and elongation also is increasing. So far, bioplastic with concentration $6 \%$ of compatibilizer chosen as the best morphological and mechanical properties because it has the best surface area and has high tensile strength and the highest value of elongation from other sample. Therefore, another test is needed to determine what the best concentration for mixing PVAg-MA/chlorella bioplastic.

\section{Aknoledgment}

We gratefully acknowledge University of Indonesia for the commonwealth awarded to the first author and for funding this project through the Research Grant Scheme from Publikasi International Terindeks untuk Tugas Akhir Mahasiswa (PITTA) grant (No.2416/UN2.R3.1/HKP.05.00/2018).

\section{References}

1. Wisojodharmo, L. A. (2001, Agustus 8). "Upaya Penanganan Limbah Plastik Di Indonesia Dan Di Dunia".pp 12-19.

2. Guerrero, M. G. (2007). Outdoor Cultivation Of Microalgae For Caretenoid Production: Current State And Perspecticve. Applied Microbiology And Biotechnology, pp 1163-1174.

3. Isnansetyo, A., \& Kurniastuti. (1995). Teknik Kultur Phytoplankton Zooplankton Pakan Alami Untuk Pembenihan Organisme Laut. Kanisius, 116.

4. Zeller, M. A., Hunt, R., Jones, A., \& Sharma, S. (2013). Bioplastics And Their Thermoplastic Blends From Spirulina And Chlorella Microalgae. Journal of Applied Polymer Science, 000-000.

5. Zhu, N., Ye, M., \& Chen Mingqing. (2017). Reactive Compatibilization Of Biodegradable Poly(Butylene Succinate)/Spirulina Microalgae Composites. Macromolecular Research, 25(2), 165-171.

6. Waryat. (2013). Rekayasa Proses Produksi Bioplastik Berbahan Baku Pati Termoplastik Dan Polietilen. Bogor: Institut Pertanian Bogor. 